\title{
Environmental variation in the prevalence of hypertension in children and adolescents - is blood pressure higher in children and adolescents living in rural areas?
}

\author{
Małgorzata Krzywińska-Wiewiorowska', Barbara Stawińska-Witoszyńska', Alicja Krzyżaniak', \\ Maria Kaczmarek ${ }^{2}$, Aldona Siwińska ${ }^{3}$ \\ ${ }^{1}$ Department of Epidemiology Chair of Social Medicine, Poznan University of Medical Sciences, Poland \\ ${ }^{2}$ Institute of Anthropology, Faculty of Biology, Adam Mickiewicz University, Poznan, Poland \\ ${ }^{3}$ Department of Pediatric Cardiology and Nephrology, Poznan University of Medical Sciences, Poland
}

Krzywińska-Wiewiorowska M, Stawińska-Witoszyńska B, Krzyżaniak A, Kaczmarek M, Siwinska A. Environmental variation in the prevalence of hypertension in children and adolescents - is blood pressure higher in children and adolescents living in rural areas? Ann Agric Environ Med. 2017; 24(1): 129-133. doi: 10.5604/12321966.1230678

\begin{abstract}
Introduction. Despite considerable progress in diagnostic methods and treatment options, cardiovascular diseases constitute a serious health issue in Poland, and hypertension is considered one of the main risk factors in the incidence of the diseases.

Objectives. The aim of this study is to assess the values of arterial blood pressure among adolescents in the context of urban and rural environments.

Materials and method. The study was carried out on a representative, randomly selected group of youths aged 10-18 years, participating in the ADOPOLNOR project. Prior to blood pressure measurement, each pupil was assessed according to anthropomorphic principles. The BP measurements strictly followed the guidelines of the Fourth Protocol of the American Working Group of High Blood pressure in Children and Adolescents.

Results. Mean values of systolic blood pressure (SBP) in boys in rural areas were higher in every age group than in the boys in urban areas. Higher values of systolic and diastolic blood pressure were observed also in girls in rural areas. BP values sufficiently high for the diagnosis of hypertension were observed in $12.8 \%$ of the rural boy population but only in $6.7 \%$ of the boys from the urban environment. The difference is statistically significant. The girls in rural areas (13.3\%) had twice the incidence of elevated BP values in comparison with the girls in urban areas (7.2\%) and, as in boys, the difference is statistically significant.

Conclusions. The high proportion of pupils with elevated arterial blood pressure observed in the rural areas of Wielkopolska calls for regularly performed BP assessment and monitoring in this population.
\end{abstract}

\section{Key words}

environmental differences, adolescents, arterial blood pressure

\section{INTRODUCTION}

Despite considerable progress in diagnostic methods and treatment options, cardiovascular diseases constitute a serious health issue in Poland, and hypertension is considered one of the main risk factors in the incidence of the diseases. The latest extended epidemiological studies (WOBASZ) have indicated that hypertension prevalence in Poland is still high and amounts to $36 \%$ of the adult population [1]. When compared to the NATPOL PLUS study from 2002, this proportion is higher by $6 \%$ (30\% vs. 36\%) [2]. Wielkopolska Province belongs to those regions of Poland where the percentage of adults with hypertension is the highest. Hypertension in the adult male population in Wielkopolska equals $50 \%$ and is the highest when compared with other Polish provinces, whereas with respect to this parameter among women, Wielkopolska has ranked second (37\%) [1].

Address for correspondence: Małgorzata Krzywińska-Wiewiorowska, Department of Epidemiology Chair of Social Medicine, Poznan University of Medical Sciences, Poland

E-mail:mwiewior@ump.edu.pl

Received: 27 February 2014; accepted: 20 May 2014; first published on January, 2017
Programmes for primary and secondary prevention of complications of hypertension should be based on early detection and control of the adjustable risk factors. Consequently, effective prevention of hypertension should start as early as in childhood. It is also known that the process of atherosclerotic lesion formation can begin in puberty. The adolescents who enter adulthood with elevated blood pressure are more likely to be diagnosed with hypertension as adults. The phenomenon of persistently elevated blood pressure in childhood being carried on to adulthood is called tracking [3].

Epidemiological studies in recent decades have indicated that the proportion of adolescents with essential hypertension ranges from several to several dozen percent $[4,5]$.

Blood pressure is one of the positive health indicators, but contrary to the morphological indicators, it has a high variability, determined by genetic, prenatal and environmental factors $[6,7,8]$.

Studies examining the incidence of hypertension among adolescents in Wielkopolska carried out in 2002-2003 revealed higher BP values in rural areas than in the adolescents in the urban environment [4]. Therefore, the assessment of the prevalence of hypertension in young people which takes into 
account environmental factors (e.g. urbanization) should be an important element of the strategy to reduce the incidence of the condition.

The assessment of the environmental variations of $\mathrm{BP}$ is a valuable indicator in prevention programmes from the early period of life (especially in the school environment).

\section{OBJECTIVES}

The aim of this paper is to assess the values of arterial blood pressure in adolescents in the context of urban and rural environments.

\section{MATERIALS AND METHOD}

A cross-sectional survey was carried out between February 2009 - September 2010 on a representative, randomly stratified sample of 4,941 pupils (2,451 boys and 2,490 girls) aged 10-18 years. They were pupils in grades 5 and 6 of primary school, 1 through 3 of junior secondary and 1 to 2 of senior secondary schools in the Wielkopolska province and its capital Poznań.

The sampling design employed in the study is a twostage stratified cluster sampling plan in which (1) schools were stratified according to urbanization category, thereby

Table 1. Studied population according to place of residence

\begin{tabular}{|c|c|c|c|c|c|c|}
\hline \multicolumn{2}{|c|}{ Boys } & \multirow{2}{*}{$\begin{array}{c}\text { Age } \\
\text { (years) }\end{array}$} & \multicolumn{2}{|c|}{ Girls } & \multicolumn{2}{|c|}{ Total } \\
\hline $\begin{array}{l}\text { Rural } \\
\text { areas }\end{array}$ & $\begin{array}{l}\text { Urban } \\
\text { areas }\end{array}$ & & $\begin{array}{l}\text { Rural } \\
\text { areas }\end{array}$ & $\begin{array}{c}\text { Urban } \\
\text { areas }\end{array}$ & $\begin{array}{l}\text { Rural } \\
\text { areas }\end{array}$ & $\begin{array}{l}\text { Urban } \\
\text { areas }\end{array}$ \\
\hline 79 & 180 & 10 & 87 & 171 & 166 & 351 \\
\hline 101 & 184 & 11 & 99 & 180 & 200 & 364 \\
\hline 99 & 157 & 12 & 118 & 181 & 217 & 338 \\
\hline 108 & 153 & 13 & 112 & 168 & 220 & 321 \\
\hline 115 & 176 & 14 & 109 & 170 & 224 & 346 \\
\hline 115 & 159 & 15 & 121 & 183 & 236 & 342 \\
\hline 156 & 161 & 16 & 124 & 164 & 280 & 325 \\
\hline 109 & 168 & 17 & 98 & 158 & 207 & 326 \\
\hline 102 & 129 & 18 & 94 & 153 & 196 & 282 \\
\hline 984 & 1,467 & Total & 962 & 1,528 & 1,946 & 2,995 \\
\hline
\end{tabular}

Table 2. Descriptive statistics of systolic (SBP) and diastolic (DBP) blood pressure in boys living in rural and urban areas stratified by gender and age

\begin{tabular}{|c|c|c|c|c|c|c|c|c|c|c|c|c|c|c|}
\hline \multirow{3}{*}{$\begin{array}{c}\text { Age } \\
\text { (years) }\end{array}$} & \multicolumn{7}{|c|}{ Systolic blood pressure (Hg/mm) } & \multicolumn{7}{|c|}{ Diastolic blood pressure $(\mathrm{Hg} / \mathrm{mm})$} \\
\hline & \multicolumn{3}{|c|}{ Rural areas } & \multicolumn{3}{|c|}{ Urban areas } & \multirow[b]{2}{*}{$P$} & \multicolumn{3}{|c|}{ Rural areas } & \multicolumn{3}{|c|}{ Urban areas } & \multirow[b]{2}{*}{$P$} \\
\hline & $\mathrm{N}$ & Mean \pm SD & Range & $\mathrm{N}$ & Mean \pm SD & Range & & $\mathrm{N}$ & Mean \pm SD & Range & $\mathrm{N}$ & Mean \pm SD & Range & \\
\hline & \multicolumn{14}{|c|}{ Boys } \\
\hline 10 & 79 & $109.2 \pm 9.0$ & $90.0-133.3$ & 180 & $106.6 \pm 9.0$ & $76.3-33.3$ & * & 79 & $66.4 \pm 8.5$ & $48.3-86.6$ & 180 & $63.6 \pm 6.8$ & $46.7-85.7$ & ** \\
\hline 11 & 101 & $112.7 \pm 10.5$ & $91.7-143.3$ & 184 & $109.4 \pm 9.5$ & $84.7-150.0$ & $* *$ & 101 & $70.1 \pm 7.7$ & $53.3-89.7$ & 184 & $65.5 \pm 6.5$ & $47.7-93.3$ & ** \\
\hline 13 & 108 & $112.2 \pm 10.8$ & $91.7-141.7$ & 153 & $113.3 \pm 8.8$ & $90.0-134.7$ & & 108 & $66.8 \pm 6.5$ & $53.3-81.7$ & 153 & $65.5 \pm 7.2$ & $43.3-83.3$ & \\
\hline 14 & 115 & $116.5 \pm 11.6$ & 86.7-156.7 & 176 & $116.8 \pm 10.1$ & $89.0-148.0$ & & 115 & $69.2 \pm 7.2$ & $48.0-90.0$ & 176 & $66.5 \pm 7.5$ & $45.7-86.7$ & ** \\
\hline 15 & 115 & $119.1 \pm 12.9$ & $94.7-160.0)$ & 159 & $115.9 \pm 10.1$ & $91.7-148.3$ & * & 115 & $70.8 \pm 9.2$ & 46.7-93.3 & 159 & $66.3 \pm 7.7$ & $50.0-81.7$ & ** \\
\hline 16 & 156 & $120.7 \pm 11.7$ & $90.0-166.7$ & 161 & $119.0 \pm 10.2$ & $91.7-148.3$ & & 156 & $72.8 \pm 7.3$ & $58.3-93.3$ & 161 & $69.7 \pm 7.6$ & $51.0-97.3$ & ** \\
\hline 17 & 109 & $122.3 \pm 11.1$ & $94.7-163.3$ & 168 & $122.2 \pm 10.9$ & $93.3-150.0$ & & 109 & $73.7 \pm 7.6$ & $53.3-93.3$ & 168 & $72.1 \pm 7.4$ & $54.7-95.0$ & \\
\hline
\end{tabular}

covering urban areas, including the city of Poznań, large and small towns as well as rural areas, and randomly selected per each stratum. The development of the sampling frame comprised: developing a list of localities for Wielkopolska province broken down into: large cities (from 50,000 $499,999)$, large towns of over 50,000, small towns below 49,999 , and villages; developing a list of schools sorted by localities and types (elementary junior secondary and senior secondary schools). In the second stage of the sampling procedure (2), one class out of every 6 in the target population in each school was chosen. In most villages, however, the students were assigned to only one class of each year level group. The survey was a part of the ADOPOLNOR project described in detail elsewhere [9]. The survey protocol was approved by Bioethics Commission at Poznań University of Medical Sciences.

The studied population encompassed $1 \%$ of the young people aged $10-18$ years $(0.8 \%$ in rural areas and $1.2 \%$ in urban areas), permanently resident in the province of Wielkopolska.

Prior to blood pressure taking, each pupil was measured for height, weight and arm circumference (in order to match appropriate cuff size), as well as waist circumference according to anthropomorphic principles [10]. Assessment of the prevalence of obesity was performed with BMI (body mass expressed in $\mathrm{kg} /$ height $^{2}$ in metres), adopting Cole's cut-off values [11], as well as waist to height ratio according to the formula $\mathrm{WHtR}=\mathrm{WC} / \mathrm{B}-\mathrm{v}$, where $\mathrm{WC}=$ waist circumference (in centimetres), B-v = body height (in centimetres) [12].

The BP measurements were made before noon, three times at 2-day and 3-day intervals, strictly following the guidelines of the Fourth Protocol of the American Working Group of High Blood Pressure in Children and Adolescents (each measurement was performed twice daily) [13]. The pupils whose mean systolic and/or diastolic blood pressure (at 3 measurements taken on different days) was equal or higher than the 95 percentile, were classified into the hypertension group. The biological benchmark was the Polish standard percentile grids presenting arterial blood pressure correlated with body height [14].

A database was created in Microsoft Excel 2007. All statistical computations were run using the Statistica data analysis software system, version 9.0 (2009). Analytical models comprised both uni- and multivariate approaches. The level of significance was set at $\mathrm{p}<0.05$.

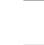


Assessment of blood pressure in relation to the degree of urbanization was performed based on the analysis of variance. In the age categories, the values of blood pressure in the urban and rural areas were compared by means of the t-student test. The relationship between the environment and the prevalence of hypertension was calculated based on the Pearson chi-square test.

\section{RESULTS}

The mean values of systolic blood pressure in boys in rural areas were higher in every age group in comparison with the boys in urban areas. However, the differences were statistically significant only in the groups of 12 -year and 16-year-olds, as well as in the whole population. Diastolic blood pressure was significantly higher in all age groups among the studied boys in rural areas, except for the groups of 10-year and 18-year-olds (Tab. 2).

Table 3. Descriptive statistics of systolic (SBP) and diastolic (DBP) blood pressure in girls living in rural and urban areas stratified by gender and age

\begin{tabular}{|c|c|c|c|c|c|c|c|c|c|c|c|c|c|c|}
\hline \multirow{3}{*}{$\begin{array}{c}\text { Age } \\
\text { (years) }\end{array}$} & \multicolumn{7}{|c|}{ Systolic blood pressure $(\mathrm{Hg} / \mathrm{mm})$} & \multicolumn{7}{|c|}{ Diastolic blood pressure $(\mathrm{Hg} / \mathrm{mm})$} \\
\hline & \multicolumn{3}{|c|}{ Rural areas } & \multicolumn{3}{|c|}{ Urban areas } & & \multicolumn{3}{|c|}{ Rural areas } & \multicolumn{3}{|c|}{ Urban areas } & \multirow[b]{2}{*}{$P$} \\
\hline & $\mathrm{N}$ & Mean $\pm S D$ & Range & $\mathrm{N}$ & Mean \pm SD & Range & $P$ & $\mathrm{~N}$ & Mean \pm SD & Range & $\mathrm{N}$ & Mean \pm SD & Range & \\
\hline & \multicolumn{14}{|c|}{ Girls } \\
\hline 10 & 87 & $109.3 \pm 11.2$ & $88.3-146.7$ & 171 & $106.6 \pm 8.3$ & $85.0-131.7)$ & * & 87 & $67.4 \pm 8.5$ & $45.0-88.3$ & 171 & $63.8 \pm 6.2$ & $50.0-86.3$ & ** \\
\hline 11 & 99 & $110.6 \pm 9.4$ & $90.0-143.3$ & 180 & $108.5 \pm 8.7$ & $90.0-130.0$ & & 99 & $67.1 \pm 7.8$ & $50.0-90.0$ & 180 & $64.6 \pm 6.4$ & $43.3-84.0$ & ** \\
\hline 12 & 118 & $113.3 \pm 10.9$ & $95.0-150.0$ & 181 & $110.3 \pm 9.2$ & $92.3-146.7$ & * & 118 & $68.0 \pm 8.4$ & $51.7-96.7$ & 181 & $65.3 \pm 6.8$ & $46.7-88.3$ & ** \\
\hline 13 & 112 & $112.8 \pm 12.1$ & $88.3-151.7$ & 168 & $111.2 \pm 9.7$ & $91.7-141.7$ & & 112 & $67.4 \pm 7.7$ & $50.0-91.7$ & 168 & $65.6 \pm 6.9$ & $43.3-87.0$ & * \\
\hline 14 & 109 & $113.9 \pm 12.8$ & $86.7-152.7$ & 170 & $112.3 \pm 10.8$ & $88.0-150.3$ & & 109 & $68.5 \pm 7.9$ & $51.7-93.3$ & 170 & $66.0 \pm 8.1$ & $50.0-91.7$ & * \\
\hline 15 & 121 & $115.6 \pm 12.2$ & $90.0-153.8$ & 183 & $112.6 \pm 10.4$ & 81.9-153.3 & * & 121 & $69.1 \pm 7.8$ & $53.3-98.3$ & 183 & $66.7 \pm 6.9$ & $50.0-81.7$ & ** \\
\hline 16 & 124 & $113.7 \pm 11.0$ & $90.7-143.3$ & 164 & $112.3 \pm 9.8$ & $88.3-141.7$ & & 124 & $70.3 \pm 7.8$ & $53.3-91.7$ & 164 & $68.1 \pm 6.9$ & $51.7-91.7$ & * \\
\hline 17 & 98 & $111.9 \pm 8.9$ & $90.9-145.0$ & 158 & $112.4 \pm 8.9$ & $91.7-143.3$ & & 98 & $70.4 \pm 8.1$ & $56.3-90.0$ & 158 & $68.2 \pm 6.4$ & $51.7-92.0$ & * \\
\hline 18 & 94 & $113.4 \pm 11.2$ & 91.7-146.7) & 153 & $111.7 \pm 10$ & $83.3-143.3$ & & 94 & $71.3 \pm 7.6$ & 56.7-91.7) & 153 & $68.0 \pm 7.0$ & $53.3-85.7$ & ** \\
\hline
\end{tabular}

Table 4. The prevalence of elevated blood pressure in boys and girls according to the environment (urban-rural)

\begin{tabular}{|c|c|c|c|c|c|c|c|c|c|c|c|c|}
\hline \multirow{4}{*}{$\begin{array}{l}\text { Age } \\
\text { (years) }\end{array}$} & \multicolumn{12}{|c|}{ Boys } \\
\hline & \multicolumn{6}{|c|}{ Rural areas } & \multicolumn{6}{|c|}{ Urban areas } \\
\hline & \multicolumn{2}{|c|}{ SBP only } & \multicolumn{2}{|c|}{ DBP only } & \multicolumn{2}{|c|}{$\mathrm{SBP}+\mathrm{DBP}$} & \multicolumn{2}{|c|}{ SBP only } & \multicolumn{2}{|c|}{ DBP only } & \multicolumn{2}{|c|}{$\mathrm{SBP}+\mathrm{DBP}$} \\
\hline & $\mathrm{N}$ & $\%$ & $\mathrm{~N}$ & $\%$ & $\mathrm{~N}$ & $\%$ & $\mathrm{~N}$ & $\%$ & $\mathrm{~N}$ & $\%$ & $\mathrm{~N}$ & $\%$ \\
\hline 10 & 0 & 0.00 & 1 & 2.63 & 2 & 5.26 & 7 & 6.14 & 1 & 0.88 & 0 & 0.00 \\
\hline 11 & 2 & 2.13 & 7 & 7.45 & 5 & 5.32 & 5 & 2.76 & 3 & 1.66 & 4 & 2.21 \\
\hline 12 & 5 & 5.75 & 3 & 3.45 & 4 & 4.60 & 4 & 2.41 & 1 & 0.60 & 3 & 1.81 \\
\hline 13 & 3 & 3.19 & 2 & 2.13 & 3 & 3.19 & 1 & 0.73 & 3 & 2.19 & 2 & 1.46 \\
\hline 14 & 8 & 7.27 & 2 & 1.82 & 3 & 2.73 & 8 & 4.85 & 3 & 1.82 & 0 & 0.00 \\
\hline 15 & 2 & 2.00 & 3 & 3.00 & 6 & 6.00 & 5 & 2.89 & 1 & 0.58 & 1 & 0.58 \\
\hline 16 & 6 & 4.23 & 5 & 3.52 & 11 & 7.75 & 7 & 5.15 & 3 & 2.21 & 1 & 0.74 \\
\hline 17 & 10 & 7.35 & 4 & 2.94 & 6 & 4.41 & 7 & 4.32 & 4 & 2.47 & 2 & 1.23 \\
\hline 18 & 7 & 4.86 & 5 & 3.47 & 6 & 4.17 & 10 & 5.00 & 4 & 2.00 & 6 & 3.00 \\
\hline \multirow[t]{2}{*}{ Total } & 43 & 4.55 & 32 & 3.39 & 46 & 4.87 & 54 & 3.77 & 23 & 1.60 & 19 & 1.32 \\
\hline & \multicolumn{12}{|c|}{ Girls } \\
\hline \multirow{3}{*}{$\begin{array}{l}\text { Age } \\
\text { (years) }\end{array}$} & \multicolumn{6}{|c|}{ Rural areas } & \multicolumn{6}{|c|}{ Urban areas } \\
\hline & \multicolumn{2}{|c|}{ SBP only } & \multicolumn{2}{|c|}{ DBP only } & \multicolumn{2}{|c|}{$\mathrm{SBP}+\mathrm{DBP}$} & \multicolumn{2}{|c|}{ SBP only } & \multicolumn{2}{|c|}{ DBP only } & \multicolumn{2}{|c|}{$\mathrm{SBP}+\mathrm{DBP}$} \\
\hline & $\mathrm{N}$ & $\%$ & $\mathrm{~N}$ & $\%$ & $\mathrm{~N}$ & $\%$ & $\mathrm{~N}$ & $\%$ & $\mathrm{~N}$ & $\%$ & $\mathrm{~N}$ & $\%$ \\
\hline 10 & 2 & 6,67 & 3 & 10.00 & 0 & 0.00 & 8 & 6.72 & 0 & 0.00 & 1 & 0.84 \\
\hline 11 & 7 & 7,87 & 4 & 4.49 & 1 & 1.12 & 4 & 2.16 & 2 & 1.08 & 0 & 0.00 \\
\hline 12 & 5 & 4,81 & 4 & 3.85 & 4 & 3.85 & 4 & 2.13 & 3 & 1.60 & 3 & 1.60 \\
\hline 13 & 12 & 11,32 & 1 & 0.94 & 5 & 4.72 & 7 & 3.95 & 3 & 1.69 & 1 & 0.56 \\
\hline 14 & 7 & 7,22 & 2 & 2.06 & 3 & 3.09 & 6 & 3.87 & 3 & 1.94 & 4 & 2.58 \\
\hline 15 & 12 & 10,00 & 2 & 1.67 & 7 & 5.83 & 8 & 4.26 & 2 & 1.06 & 2 & 1.06 \\
\hline 16 & 9 & 6,92 & 3 & 2.31 & 3 & 2.31 & 9 & 4.57 & 3 & 1.52 & 2 & 1.02 \\
\hline 17 & 6 & 6,74 & 6 & 6.74 & 2 & 2.25 & 8 & 5.52 & 4 & 2.76 & 2 & 1.38 \\
\hline 18 & 3 & 2,22 & 2 & 1.48 & 5 & 3.70 & 3 & 1.67 & 4 & 2.22 & 2 & 1.11 \\
\hline Total & 63 & 7,00 & 27 & 3.00 & 30 & 3.33 & 57 & 3.72 & 24 & 1.56 & 17 & 1.11 \\
\hline
\end{tabular}


As in boys, higher values of systolic and diastolic blood pressure were observed in girls in rural areas. However, for the systolic BP the differences were statistically significant only for the 11-, 13-, and 15-year-olds, whereas the differences in the values of diastolic BP were statistically significant in all groups, except for 14- and 17-year-olds (Tab. 3).

$\mathrm{BP}$ values which constituted hypertension diagnosis were observed in $12.8 \%$ of the boys of the rural population as well as in $6.7 \%$ of the tested pupils from the urban environment, and the differences were statistically significant (Tab. 4). Girls in rural areas (13.3\%) had twice the percentage of elevated BP values in comparison with urban girls (7.2\%) and, as in boys, the differences were statistically significant (Tab. 4).

\section{DISCUSSION}

The study results show higher values of arterial blood pressure, as well as higher proportions of pupils with elevated arterial blood pressure values in the rural environment, which supports the diagnosis of hypertension, in comparison with the children in urban areas. One of the reasons for the disparity may be the inherent variation in morphological indices between the 2 environments. There are significant differences in body height between the young urban and rural populations, in both genders, in favour of urban adolescents. Boys in rural areas were shorter than those in urban areas, and the same for girls. The rural pupils also had a higher body mass than urban children [15].

It is difficult to give reasons for the environmental diversification of the physiological characteristics of which blood pressure is a part. This stems from the proven relationship between blood pressure and body height, and this particular morphological quality is strongly genetically determined. Body mass, in turn, which may affect the level of arterial blood pressure, depends more on environmental factors and life-style $[6,7,8,16]$. There is also a significant variation in the WHtR values between girls in rural and urban settings. The urban girls were found to have lower WHtRs, thus showing a lower accumulation of abdominal fat, compared to their rural peers. No significant differences were found in WHtR values between boys in rural and urban areas [15].

The influence of the pace of physical development on the $\mathrm{BP}$ value (especially during puberty) is also not without significance.

The prevalence of family history of hypertension, cardiovascular diseases and diabetes, as well as obesity, was higher among the studied pupils in rural than in urban areas.

Persistently elevated arterial blood pressure in high percentile values, and the fast rate of its increase, especially during puberty, may be an important prognostic of hypertension developing later in adulthood (tracking) $[3,17,18]$.

The wide environmental variations of morphological characteristics were observed in Poland particularly in the 1960s and 70s. [19].

Studies related to regional variations of morphological parameters and arterial blood pressure in Polish children and adolescents that have been recently presented, show only minor differences in these indices between the pupils living in the regions of Eastern and Central Poland with a higher GNP (Gross National Product).
The tendency of having persistently elevated arterial blood pressure among pupils in rural area had already been observed in research conducted in the province of Wielkopolska in 2003 [4]. A similar phenomenon was also described by Kowalska and Krzych in the Silesian region, although there it was mainly elevated diastolic BP levels detected among pupils from primary school, inhabitants of small towns and villages [20].

The most recent epidemiological research concerning the prevalence of metabolic syndrome in the Polish adult population (WOBASZ) indicated that abdominal obesity and hypertension occur preferentially in agricultural provinces [21].

\section{CONCLUSIONS}

The high proportion of pupils with elevated arterial blood pressure observed in the rural areas of Wielkopolska calls for regularly performed BP assessment and monitoring in this population.

\section{Acknowledgements}

This study was supported by research funds in 2004-2008 and co-financed by Grants from Iceland, Liechtenstein and Norway through the EEA Financial Mechanism and the Norwegian Financial Mechanism, Project PL0255 ADOPOLNOR.

\section{REFERENCES}

1. Tykarski A, Posadzy-Małaszyńska A, Wyrzykowski B, Kwaśniewska M, Pająk A, Kozakiewicz K, Rywik S, Broda G. Rozpowszechnienie nadciśnienia tętniczego oraz skuteczność jego leczenia u dorosłych mieszkańców naszego kraju. Wyniki programu WOBASZ. Kardiol Pol. 2005; 63: 6 (supl. 4) (in Polish).

2. Zdrojewski A, Bandosz P, Szpakowski P, Konarski R, Wołkiewicz E, Kozicka-Kąkol K, Krupa-Wojciechowska B, Wyrzykowski B. Ocena wybranych problemów dotyczących rozpowszechnienia i terapii nadciśnienia tętniczego w Polsce na podstawie badania NATPOL PLUS Postępy w nefrologii i nadciśnieniu tętniczym, T. 2, 2002 (in Polish).

3. Muntner P, He J, Cutler JA, Wildman RP, Whelton PK. Trends in blood pressure among children and adolescents. JAMA 2004; 291: 2107-2113.

4. Krzyżaniak A, Stawińska-Witoszyńska B, Szilágyi-Pągowska I. Palczewska I. Ciśnienie tętnicze dzieci i młodzieży województwa mazowieckiego i wielkopolskiego. Poznań 2004, Prz Lek. 2003; 60 supl. 6 (in Polish).

5. Kulaga Z, Litwin M, Zajaczkowska M, Wasilewska A, Tkaczyk M, Gurzkowska B, et al. Regionalne różnice parametrów antropometrycznych oraz ciśnienia tętniczego uczniów w wieku 7-18 lat. Probl Hig Epidemiol. 2009; 90(1): 32-41 (in Polish).

6. Wolański N. Rozwój biologiczny człowieka. Podstawy auksologii, gerontologii i promocji zdrowia. Warszawa 2005, Wydawnictwo Naukowe PWN (in Polish).

7. Suliburska J, Bogdański P, Duda G, Pupek-Musialik D, Piątek J, Żukiewicz-Sobczak W. An assessment of dietary intake and state of nutritional in hypertensive patients from rural and urban areas of Greater Poland. Ann Agric Environ Med. 2012; 19(3): 339-43.

8. Szuba A, Martynowicz H, Zatońska K, Ilow R, Regulska-Ilow B, Różańska D, Wołyniec M, Einhorn J, Vatten L, Asvold BO, Mańczuk M, Zatoński WA. Prevalence of hypertension in a sample of Polish population - baseline assessment from the prospective cohort 'PONS' study. Ann Agric Environ Med. 2011 Dec; 18(2): 260-4.

9. Kaczmarek M. Conceptual frameworks and methodological tools for multidisciplinary approach to the adolescent health research. In: M. Kaczmarek (ed.): Health and Well-Being in Adolescence. Part I. Physical health and Psychological Well-being. Poznań: Bogucki Wydawnictwo Naukowe, 2011: 19-43. 
10. Wolański N. Metody kontroli rozwoju fizycznego dzieci i młodzieży: wskazówki praktyczne dla lekarzy, nauczycieli, wychowawców, pielęgniarek i higienistek w placówkach służby zdrowia oraz w zakładach nauczania i wychowania dzieci. Warszawa 1965, Państ. Zakład Wydawnictw Lekarskich (in Polish).

11. Cole TJ, Bellizzi MC, Flegal KM, Dietz WH. Establishing a standard definition for child overweight and obesity worldwide: international survey. BMJ. 2000 May 6; 320(7244): 1240-3.

12. Ostrowska-Nawarycz L, Krzyżaniak A, Stawińska-Witoszyńska B, Krzywińska-Wiewiorowska M, Szilágyi-Pągowska I, Kowalska M, Krzych $€$, Nawarycz T. Percentile distributions of waist circumference for 7-19-year-old Polish children and adolescents. Obesity reviews. 2009; $1-9$.

13. The Fourth Report on the Diagnosis, Evaluation, and Treatment of High Blood Pressure in Children Adolescents National High Blood Pressure Education Program Working Group of High Blood pressure in Children Adolescents. Pediatrics, 2004; 114: 555-576.

14. Krzyżaniak A, Krzywińska-Wiewiorowska M, Stawińska-Witoszyńska B, Kaczmarek M, Krzych $€$, Kowalska M, et al. Blood Pressure references for Polish children and adolescents. Eur J Pediatr. 2009; 168: 1335-1342.

15. Durda M. Biological status of adolescents in relation to their lifestyle behaviours and family's socioeconomic status. In Kaczmarek M. editor Health and Quality of Life in Adolescence. Part I Physical Health and
Subjective Well-Being. Poznań: Bogucki Wydawnictwo Naukowe; 2011. p 111-137.

16. Hanisch D, Dittmar M, Höhler T, Alt KW. Contribution of genetic and environmental factors to variation in body compartments--a twin study in adults. Anthropol Anz. 2004 Mar; 62(1): 51-60.

17. Donahue RP, Prineas RJ, Gomes O, Hong Ch. Tracking of elevated systolic blood pressure among lean and overweight adolescents: the Minneapolis Children's Blood Pressure Study. J Hyper. 1994; 12: 303-308.

18. Carrico RJ, Sun SS, Sima AP, Rosner B. The predictive value of childhood blood pressure values for adult elevated blood pressure. Open J Pediatr. 2013 Jun; 3(2): 116-126.

19. Łaska-Mierzejewska T, Olszewska E. Biologiczne przejawy zmian sytuacji ekonomicznej rodzin wiejskich w latach 1967-2001. Polityka Społeczna. 2009; 9: 17-22.

20. Kowalska M, Krzych Ł, Krzyżaniak A, Stawińska-Witoszyńska B, Zawiasa A, Siwik P. Blood pressure distribution in children in Silesia region with regard to gender, age and the place of residence. Ann Acad Med Siles. 2006; 60(95): 87-92.

21. Wyrzykowski B, Zdrojewski T, Synowska E, Biela U, Drygas W, Tykarski, Kozakiewicz K, Broda G. Epidemiologia zespołu metabolicznego w Polsce. Wyniki programu WOBASZ. Kardiol Pol. 2005; 63: 6 (supl. 4) (in Polish). 